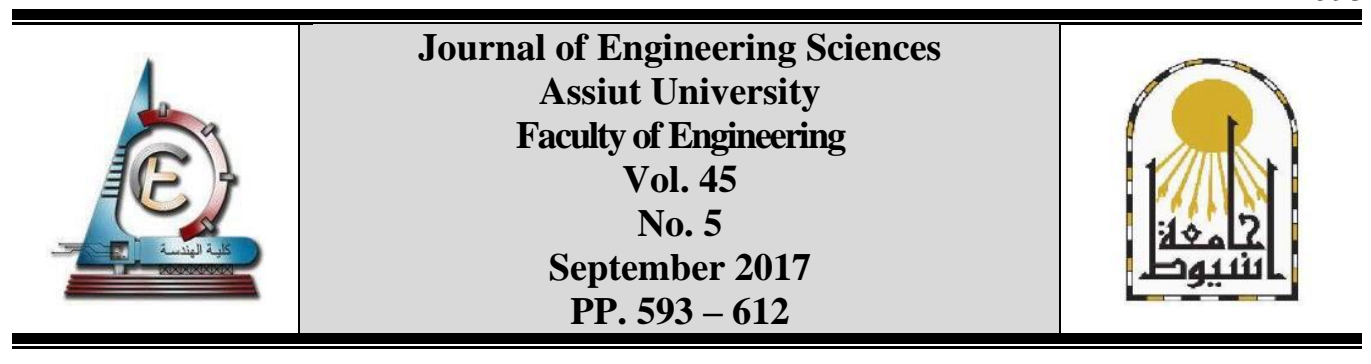

\title{
STRENGTHENING OF R.C BEAMS WITH OPENINGS CREATED AFTER CASTING USING F.R.P
}

\section{Mostafa Ahmed Mohamed and M. M. Ahmed}

Civil Engineering Department, Faculty of Engineering, Assiut University, Assiut, Egypt. Received 10 July 2017; Accepted 25 August 2017

\begin{abstract}
Web openings in beams have found many applications in practice such as they provide convenient passages of electrical and mechanical conduits. Over the past several decades, many researchers exerted great efforts to predict and interpret the behavior of beams with web openings. They recommended convenient methods for the design of such beams. These methods are successfully used if openings were decided before casting of beams. But, what will be the case if it is required to provide new openings in existing beams? The current work aims to give a satisfactory answer for this question, in which CFRP were used to strengthen and improve the behavior of beams with created openings. Eighteen reinforced concrete beams with rectangular cross section $(13 \times 25 \mathrm{~cm})$ were tested under two concentrated static load. Three of the beams were taken solid without openings as control beams. Each one of the other beams was provided with a rectangular web opening of $20 \mathrm{~cm}$ length. CFRP was used to strengthen some beams. The variable parameters are the opening height, the percentage of cut web reinforcement, the distance between the opening edge and the nearest unaffected web reinforcement, the shear span to depth ratio and type of strengthening, as well as concrete strength. The pattern of cracks, final mode of failure, cracking load, failure load and deformational characteristics (deflection, and strains) were recorded, analyzed and discussed. Finally, some important conclusions were reported.
\end{abstract}

Keywords: created web openings, openings strengthening with CFRP, Percentage of cut stirrups $\left(\rho_{s}\right)$, height of opening $(h)$, and Concrete compressive strength $f_{c u}$.

\section{Introduction}

Transverse web openings are often provided through beams to accommodate utility ducts and pipes to be benefit from the unused space above the beam soffit. It is obvious that such openings are potential source of weakness in the beams. When the service systems are preplanned and the size and location of required openings decided upon well in advance, adequate strength and serviceability may be ensured during the design stage.

This, however, is not always the case. There are at least two circumstances that necessitate drilling of holes in an existing structure. The first is in a recently constructed building, when laying the service ducts, the $M \& E$ contractor frequently comes up with the request to drill an opening for the sake of simplifying the arrangement of pipes not carefully considered during the design stage. 
The second circumstance arises in an old building. Where, the openings are created by removing concrete cores for structural assessment of the building. In such a case, however, the holes are generally filled in by non-shrink grout. If the structure is to remain, then the question is whether such a repair is adequate to restore the original level of safety and serviceability of the structure.

On the other hand, fiber-reinforced polymers (FRP) have started to be attractive new materials for structural engineers for the use in strengthening reinforced concrete beams. Carbon, Aramid, and Glass fibers are the most commonly used types in manufacturing FRP strengthening systems. Most, if not all, of these systems, however, suffer from some drawbacks when dealing with strengthening of concrete beams. They exhibit a linear stress-strain response up to failure. As a result, the steel may yield before the strengthening material even begins to carry any significant load. However, external bonding of FRP laminates become available alternative to bonding steel plates for strengthening concrete structures due to its high strength-to-weight ratio, resistance to chemicals, good fatigue strength, and nonmagnetic property. In 1999, N. F. Grace et al [1] conducted a research on the behavior of reinforced concrete beams strengthened with various types of fiber reinforced polymer (FRP) laminates, Ahmed and D. Van Gemert (1999) [2] studied the effect of cross-sectional area of the CFRP laminates on the pattern of cracks and mode of failure, the anchorage shear stress distribution, the maximum deformation, and the load carrying capacity. Mahmoud T. El - Minhilmy et al [3] investigated the deflection of reinforced concrete beams strengthened with fiber-reinforced polymer (FRP) plates. Alex Li et al [4] studied the effect of the shear strengthening of RC beams on the stress distribution, initial cracks, crack propagation, and ultimate strength. Xinbao Yang and Antonio Nanni (2001) [5] investigated the effect of fiber misalignment on the performance of concrete beams strengthened with FRP laminates, experimentally. Y. H. Hammad [6] et al 2002, investigated the shear response, including the load-carrying capacity and mode of failure, of simply supported reinforced concrete T-beam strengthened with CFRP fabrics. Sergio F. Brena et al (2003) [7] discussed the flexural behavior of reinforced concrete beams that were strengthened using four types of CFRP composites. J. Barros and S. Dias (2003) [8] presented an evaluation of the effioncy of the shear strengthening technique and compared the behavior of the beams strengthened by using CFRP laminate strips with that using conventional stirrups. Francesco Bencardino et al (2005) [9] presented a study of the behavior of RC beams externally strengthened in flexure. Venees Faied Ibrahem (2007) [10] study the strengthening of R.C beams with openings created after casting using F.R.P. The Strengthening schemes around the opening and at mid-span beam were found to be the best in reducing mid-span deflection than schemes around the opening only. Mahmoud Abdou Mahmoud Hassanean (2014) [11] studied the Behavior of High Performance R.C. Continuous Deep Beams with Openings and Its Strengthening.

In the current work, an experimental study for beam with created web openings strengthened with CFRP laminates will be presented; the main object is to study the possibility of providing rectangular web openings in an existing solid beams. It aims to declare their effect on both strength and stiffness and try to decrease their bad effects by strengthening opening zone.

The main parameters taken into considerations are:

1- The height of opening (h);

2- The percentage of cut stirrups $\left(\rho_{\mathrm{s}}\right)$; 
3- The shear span to depth ratio a/d;

4- The concrete compressive strength $\mathrm{f}_{\text {cu }}$.

5- Number of CFRP layers as a strengthening material for reinforced concrete beams.

\section{Experimental work}

\subsection{Test specimens}

In order to investigate the above points, eighteen reinforced concrete beams were prepared. All tested beams have the same total length of $2 \mathrm{~m}$ and overall cross section of $13 \times 25 \mathrm{~cm}$, as shown in Fig (1). They were simply supported with span of $1.8 \mathrm{~m}$.The steel reinforcement of all beams was: two bars $12 \mathrm{~mm}$ diameter as tension reinforcement; two bars $10 \mathrm{~mm}$ diameter as compression reinforcement and stirrups $6 \mathrm{~mm}$ diameter with $14 \mathrm{~cm}$ spacing. The beams "B01, B02 and B03" were solid without any openings and were considered as a reference beams. Each of the other beams was provided with one opening of $20 \mathrm{~cm}$ length, and $8 \mathrm{~cm}$ height for beams (B2, B5, B6, B9, B10, B11, B12 and B13) and $10 \mathrm{~cm}$ height for (B3) and $12 \mathrm{~cm}$ height for beams (B4, B7, B8, B14, B15 and B16). Details for tested reinforced concrete beams are given in Fig (1) and table (1).

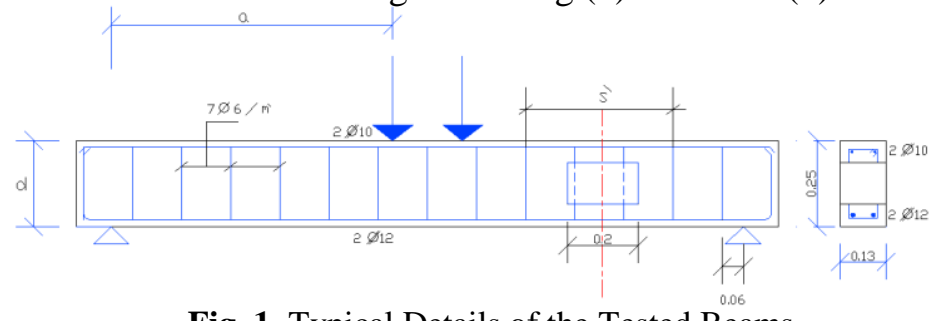

Fig. 1. Typical Details of the Tested Beams

Table 1.

Details of the tested beams

\begin{tabular}{|c|c|c|c|c|c|c|c|c|c|c|}
\hline 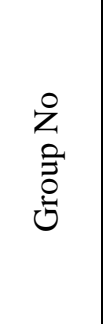 & $\begin{array}{l}\text { Beam } \\
\text { No. }\end{array}$ & $\begin{array}{l}\text { Opening } \\
\text { height } \\
\text { (h) }\end{array}$ & 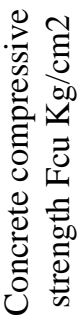 & ร) & 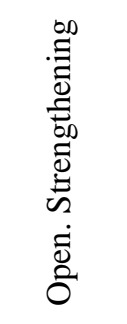 & $\begin{array}{c}\mathrm{S}^{\prime} \\
(\mathrm{cm})\end{array}$ & $\rho_{s X}{ }^{10-5}$ & 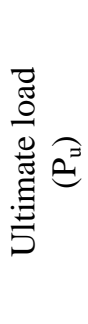 & $\begin{array}{c}\text { First } \\
\text { shear } \\
\text { crack } \\
\text { Load(t) } \\
\left(\mathrm{P}_{\text {cr. sh }}\right)\end{array}$ & 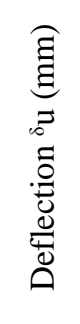 \\
\hline & B01 & \multirow{3}{*}{$\begin{array}{c}\text { Reference } \\
\text { without } \\
\text { opening }\end{array}$} & 250 & 3.5 & - & & \multirow{3}{*}{-} & 7.30 & 3.50 & 6.73 \\
\hline & B02 & & 325 & 3.5 & & & & 7.80 & 4.20 & 7.48 \\
\hline & B03 & & 450 & 3.5 & & & & 8.20 & 5.00 & 8.82 \\
\hline \multirow{3}{*}{$\begin{array}{l}0 \\
0\end{array}$} & $\mathrm{~B} 2$ & $8 \mathrm{~cm}$ & \multirow{3}{*}{250} & \multirow{3}{*}{3.5} & \multirow{3}{*}{$\begin{array}{l}\text { Without } \\
\text { layer }\end{array}$} & 28 & \multirow{3}{*}{7.69} & 4 & 2.00 & 6.05 \\
\hline & B3 & $10 \mathrm{~cm}$ & & & & 28 & & 3.70 & 1.50 & 5.78 \\
\hline & B4 & $12 \mathrm{~cm}$ & & & & 28 & & 3.50 & 1.00 & 5.56 \\
\hline \multirow{3}{*}{ 总 } & B2 & \multirow{3}{*}{$8 \mathrm{~cm}$} & \multirow{3}{*}{250} & 3.5 & \multirow{3}{*}{$\begin{array}{l}\text { Without } \\
\text { layer }\end{array}$} & 28 & \multirow{3}{*}{7.69} & 4 & 2.00 & 6.05 \\
\hline & B5 & & & 2.7 & & 28 & & 4.90 & 2.50 & 5.20 \\
\hline & B6 & & & 1.8 & & 28 & & 5.20 & 3.00 & 4.22 \\
\hline \multirow{2}{*}{ 우워 } & B4 & \multirow{2}{*}{$12 \mathrm{~cm}$} & 250 & \multirow{2}{*}{3.5} & \multirow{2}{*}{$\begin{array}{l}\text { Without } \\
\text { layer }\end{array}$} & 28 & \multirow{2}{*}{7.69} & 3.50 & 1.00 & 6.41 \\
\hline & B7 & & 325 & & & 28 & & 3.60 & 1.50 & 6.56 \\
\hline
\end{tabular}


JES, Assiut University, Faculty of Engineering, Vol. 45, No. 5, Sepember 2017, pp.593-612

\begin{tabular}{|c|c|c|c|c|c|c|c|c|c|c|}
\hline \multirow[t]{2}{*}{ 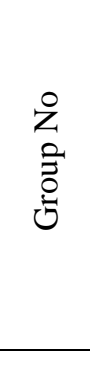 } & $\begin{array}{c}\text { Beam } \\
\text { No. }\end{array}$ & $\begin{array}{l}\text { Opening } \\
\text { height } \\
\text { (h) }\end{array}$ & 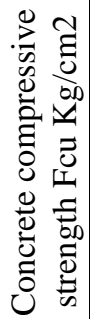 & సె & 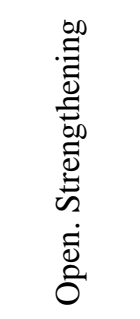 & $\begin{array}{c}\mathrm{S}^{\prime} \\
(\mathrm{cm})\end{array}$ & $\rho_{s X}{ }^{10-5}$ & 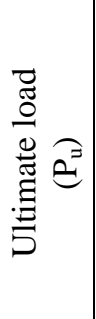 & $\begin{array}{c}\text { First } \\
\text { shear } \\
\text { crack } \\
\text { Load(t) } \\
\left(\mathrm{P}_{\text {cr. sh }}\right)\end{array}$ & 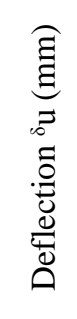 \\
\hline & B8 & & 450 & & & 28 & & 4.20 & 1.00 & 6.05 \\
\hline \multirow{3}{*}{ 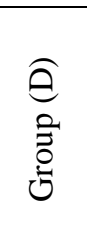 } & B9 & \multirow{3}{*}{$8 \mathrm{~cm}$} & \multirow{3}{*}{250} & \multirow{3}{*}{3.5} & $\begin{array}{l}\text { Without } \\
\text { layers }\end{array}$ & 42 & \multirow{3}{*}{5.13} & 2.40 & 2.00 & 3.05 \\
\hline & B10 & & & & $\begin{array}{l}\text { One } \\
\text { laver }\end{array}$ & 42 & & 5.50 & 4.50 & 7.30 \\
\hline & B11 & & & & $\begin{array}{c}\text { Two } \\
\text { layers }\end{array}$ & 42 & & 6.56 & 4.80 & 7.05 \\
\hline \multirow{3}{*}{ 苛 } & B11 & \multirow{3}{*}{$8 \mathrm{~cm}$} & \multirow{3}{*}{250} & \multirow{3}{*}{3.5} & \multirow{3}{*}{$\begin{array}{l}\text { Two } \\
\text { layers }\end{array}$} & 42 & 5.13 & 6.56 & - & 7.05 \\
\hline & B12 & & & & & 28 & 7.69 & 6.90 & 3.50 & 6.05 \\
\hline & B13 & & & & & 48 & 4.49 & 6.00 & 3.00 & 8.10 \\
\hline \multirow{3}{*}{ 节无 } & B14 & \multirow{3}{*}{$12 \mathrm{~cm}$} & 250 & \multirow{3}{*}{3.5} & \multirow{3}{*}{$\begin{array}{l}\text { Two } \\
\text { layers }\end{array}$} & 28 & \multirow{3}{*}{7.69} & 5.50 & 4.50 & 6.26 \\
\hline & B15 & & 325 & & & 28 & & 7.30 & 7.00 & 9.30 \\
\hline & B16 & & 450 & & & 28 & & 7.90 & 7.50 & 8.94 \\
\hline \multicolumn{11}{|c|}{$\begin{array}{l}* \mathrm{a}=\text { distance between } \\
* \mathrm{~d}=\text { depth of beam. } \\
* \mathrm{~b}=\text { width of beam. }\end{array}$} \\
\hline
\end{tabular}

U-shape stirrups are used at the opening location to simulate the cut Stirrups when drilling a hole in an existing beam.

\subsection{Strengthening scheme}

The beams, "B01","B02"and "B03", were solid and used as control beams, without any opening. In eight beams the opening was left without any strengthening to declare the effect of creating an opening in different situations. However in the other beams the opening was strengthened with CFRP sheets around it. See Table (1).

The external strengthening system using CFRP and epoxy adhesives were performed, according to the manufacture recommendation.

Variable number of layers has been used for strengthening. The inner surfaces of the opening and the beam surface adjacent to it were covered with one or two layers of CFRP sheets. The strip width was to cover the whole height of both the upper and lower chord. See Fig (2). 


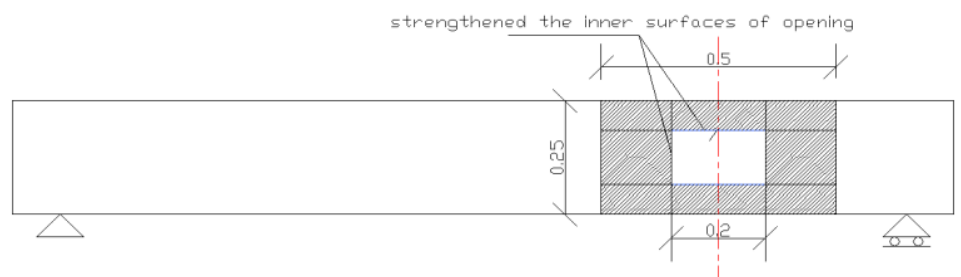

Fig. 2. Strengthening Schemes of CFRP around the opening zone.

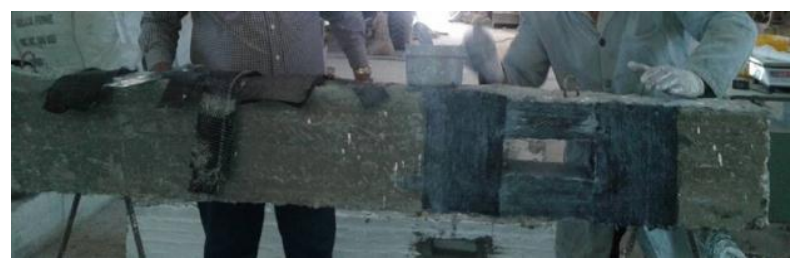

Photo1. Strengthening Schemes of CFRP around the opening zone.

\section{Test results}

\subsection{Pattern of cracks and modes of failure}

The crack pattern for the solid beam "B01", "B02" and "B03". The crack pattern is shown in Fig (3) to Fig (5), and in photo (2) to (4); the first crack was initiated vertically at the mid span of the beam bottom face at a load of $2.0 \mathrm{t}, 2.5 \mathrm{t}$ and $4 \mathrm{t}$ respectively. As the load increased, other cracks initiated and extended towards the points of load application. Diagonal cracks were observed in the shear zones at mid height at a higher load of about 3.0t. The number of cracks increased with increasing the load and finally the mode of failure, was a typical flexural one; which was occurred due to yielding, the beam failed at load of $7.3 \mathrm{t}, 7.8 \mathrm{t}$ and $8.2 \mathrm{t}$ respectively.

\subsubsection{Tested beams with variable opening height group (A)}

The crack pattern for the beam "B2" with created unstrengthened openings and (h opening $=8 \mathrm{~cm}$ ) is shown in Fig (6). The first crack was initiated at the mid span of beam at $1.5 \mathrm{t}$, while the first shear crack was initiated at opening corner nearest to the support at a load of 2.0t. As the load increased, additional, new cracks were observed at the top and bottom chord of opening, and finally the beam failed at load of $4 \mathrm{t}$ by shear photo (5). In addition, the major cracks were located at the line joining the points of opening corner and either the nearest support or the point of load application.

Fig (7) and photo (6) show the pattern of cracks and modes of failure of beam "B3". With created unstrengthened opening and ( $\mathrm{h}$ opening $=10 \mathrm{~cm}$ ), the first crack was initiated at the opening corner nearest to the support at a load of $1.5 \mathrm{t}$, while first crack at the mid span of beam was initiated at 2.0t. As the load increased, new cracks were observed at the top and bottom chord of opening, the beam failed at load of 3.7t. The critical crack was formed at the line joining the points of opening corner and either the nearest support or the point of load application. The mode of failure, as indicated by photo (6) was a typical shear failure.

The crack pattern for beam "B4" with created unstrengthened opening and (h opening $=12 \mathrm{~cm}$ ) was shown in Fig (8). The first crack was initiated at opening corner nearest to the support at a load of 1.0t. While the first crack at the mid span of beam was initiated at 2.0t. 
598

JES, Assiut University, Faculty of Engineering, Vol. 45, No. 5, Sepember 2017, pp.593-612

As the load increased, new cracks were observed in the top and bottom chord of opening. The beam failed by shear at opening zone at load of 3.5t. The major crack was located at the line joining the points of opening corner and either the nearest support or the point of load application. The mode of failure, as indicated by photo (7) was also a typical shear failure.

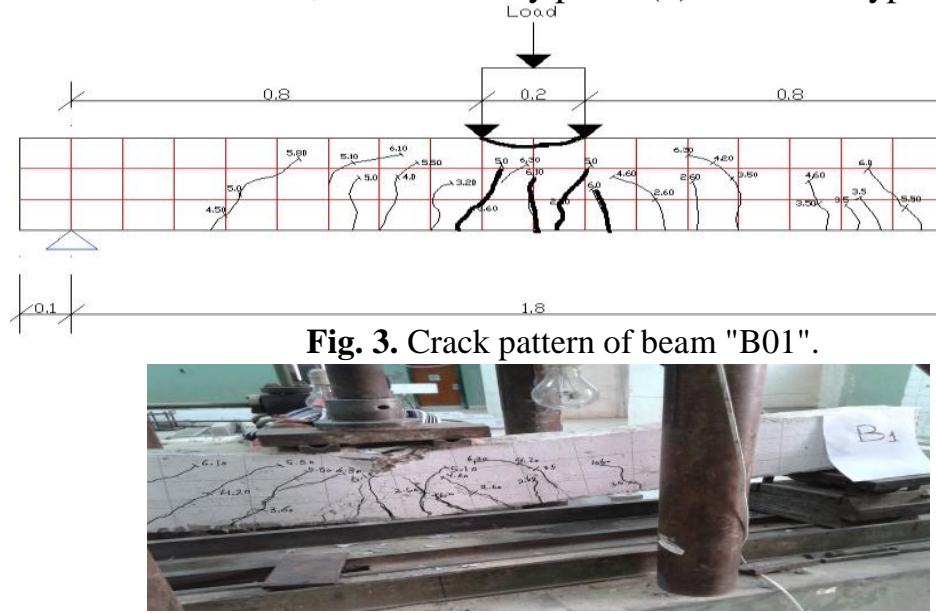

Photo 2. Crack pattern of beam "B01".

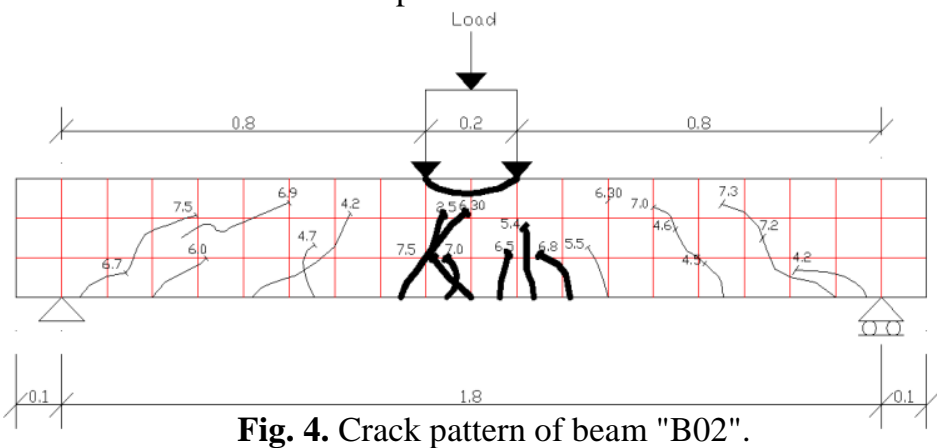

Fig. 4. Crack pattern of beam "B02".

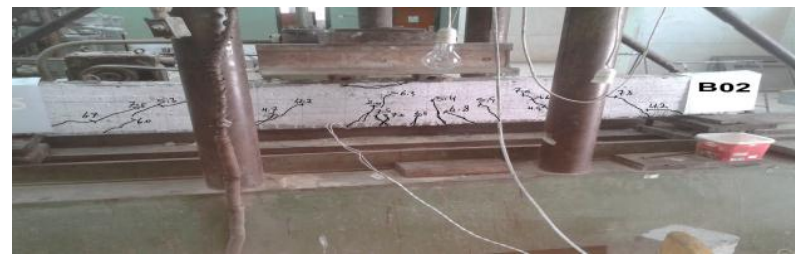

Photo 3. Crack pattern of beam "B02".

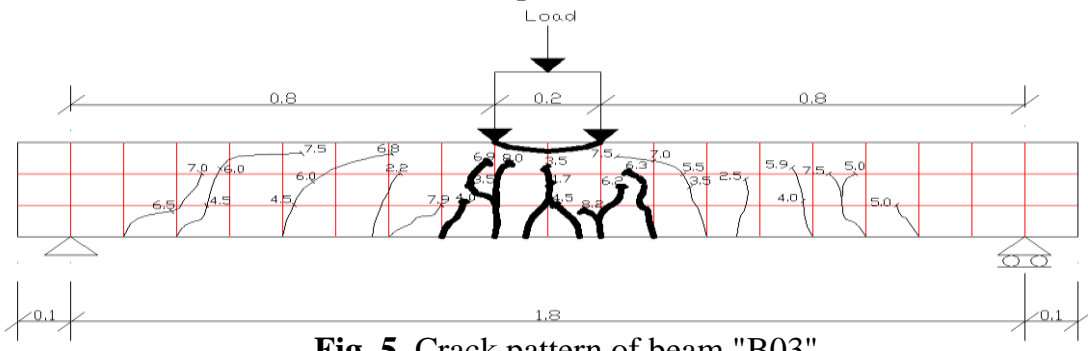

Fig. 5. Crack pattern of beam "B03" 

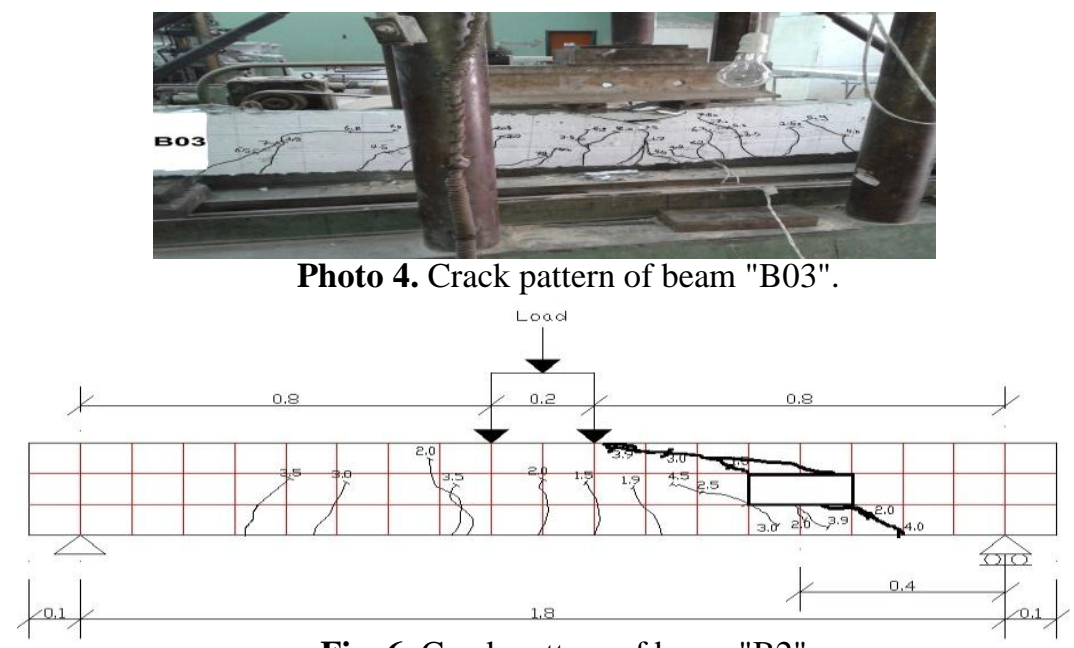

Fig. 6. Crack pattern of beam "B2".

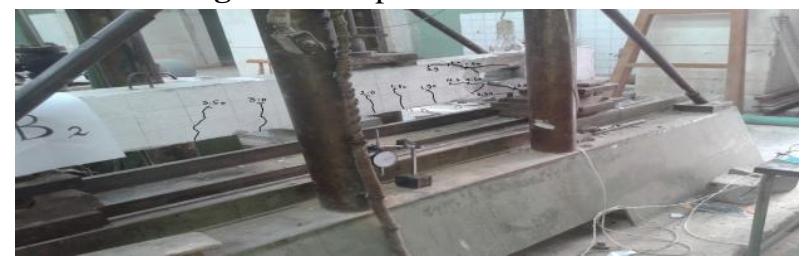

Photo 5. Crack pattern of beam "B2".

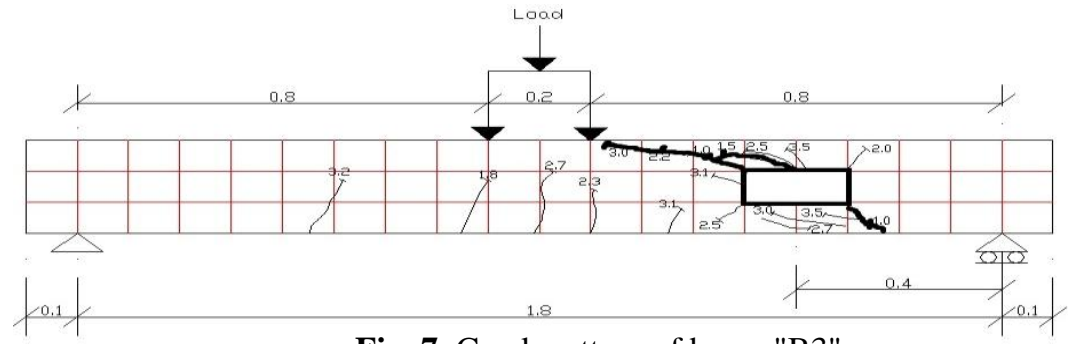

Fig. 7. Crack pattern of beam "B3".

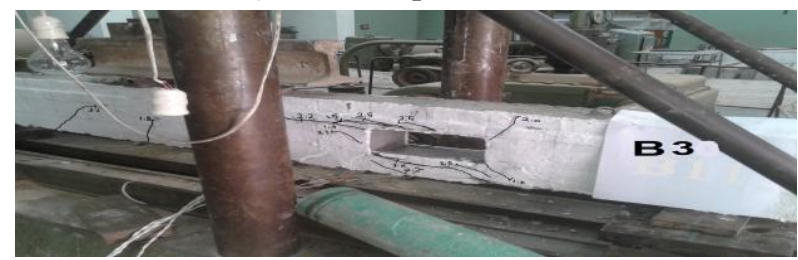

Photo 6. Crack pattern of beam "B3".

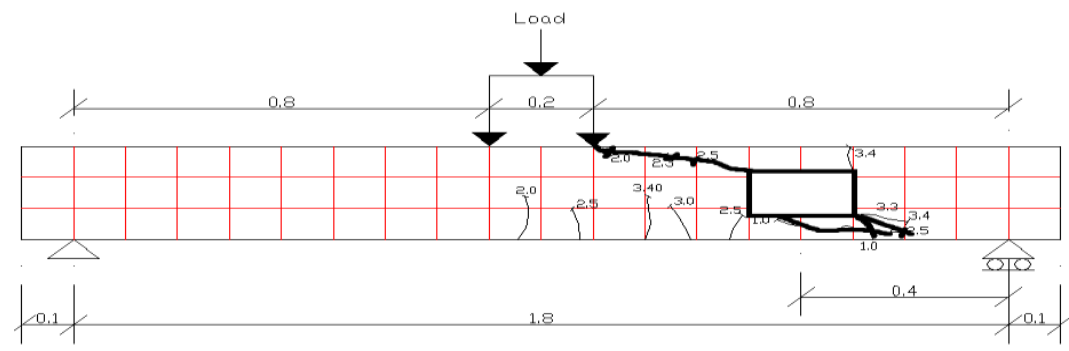

Fig. 8. Crack pattern of beam "B4". 


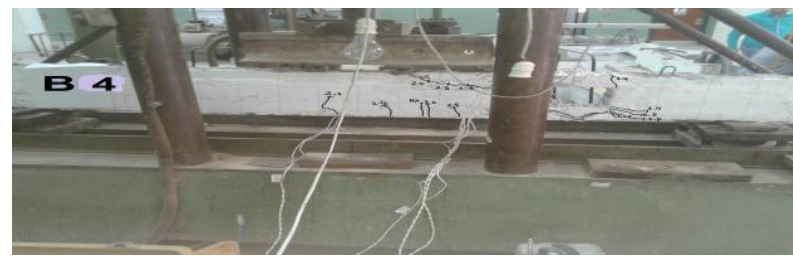

Photo 7. Crack pattern of beam "B4".

\subsubsection{Tested beams with variable a/d ratio, group $(B)$}

The pattern of cracks for beam "B2" with $\mathrm{a} / \mathrm{d}=3.5$ is mentioned before in item (2.1.1).

For beam "B5" with created unstrengthened opening and $(\mathrm{a} / \mathrm{d}=2.7)$ the crack pattern is shown in Fig (9), The first crack at the mid span of beam was initiated at 1.5t, However first crack at the shear zone was initiated at opening corner nearest to the support at a load level of about 2.5t. As the load increased, additional, new cracks were observed at the top and bottom chord of opening, the beam failed by shear at load of 4.9t. In addition, the major crack were located at the line joining the points of opening corners and either the nearest support or the point of load application. The mode of failure, as indicated by photo (8) was a typical shear failure.

For beam "B6" with created unstrengthened opening and $(\mathrm{a} / \mathrm{d}=1.8)$ was shown in Fig (10), the first crack was initiated at the mid span of beam at $2.5 \mathrm{t}$, while the first crack at opening zone was initiated at the opening corner nearest to the support at a load of 3.5t. As the load increased, circumferential cracks were observed at the top and bottom chord of opening, the beam failed also by shear at load of 7.5t. The major cracks were located at the line joining the points of opening corner and either the nearest support or the point of load application. The mode of failure, as indicated by photo (9) was a typical shear failure.

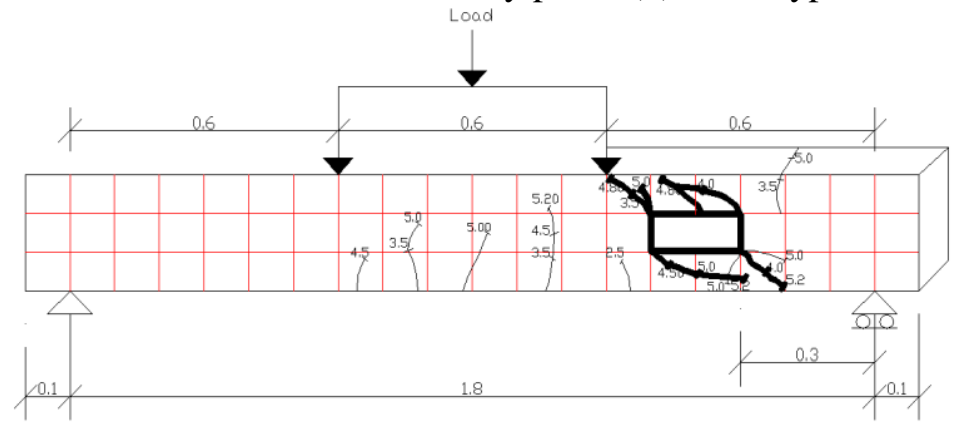

Fig. 9. Crack pattern of beam "B5".

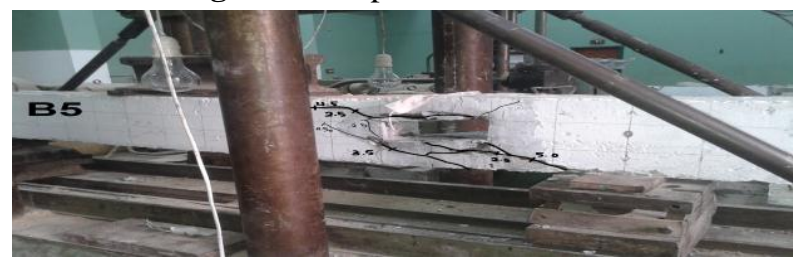

Photo 8. Crack pattern of beam "B5". 


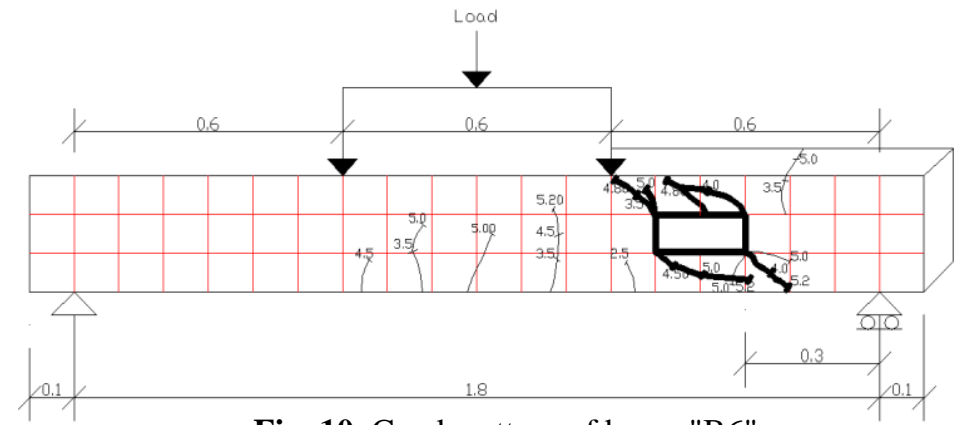

Fig. 10. Crack pattern of beam "B6".

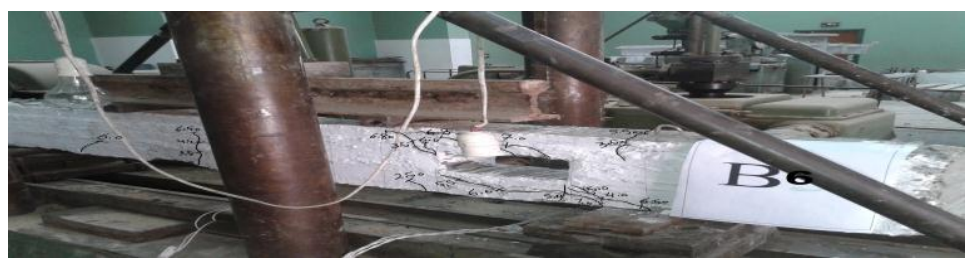

Photo 9. Crack pattern of beam "B6".

\subsubsection{Tested beams with unstrengthened opening and variable $F_{c u}$, group $(C)$}

The pattern of cracks for beam "B4" with $\mathrm{F}_{\mathrm{cu}}=250 \mathrm{~kg} / \mathrm{cm}^{2}$ is mentioned before in item (2.1.1).

The crack pattern for beam "B7" with created unstrengthened opening and $\left(\mathrm{f}_{\mathrm{cu}}=325 \mathrm{~kg} / \mathrm{cm}^{2}\right)$ shown in Fig (11), the first crack was initiated at the opening corner nearest to the support at a load of $1.5 \mathrm{t}$, and first crack was initiated at the mid span of beam at 2.0t. As the load increased, other cracks were observed in the top and bottom chord of opening, the beam failed by shear at load of 3.6t. A horizontal crack in the bottom chord was formed prior to failure owing to the absence of effective transverse reinforcement. The mode of failure, as indicated by photo (10) was a typical shear failure, along the line joining the load point and the support through the opening.

The crack pattern for beam "B8" with created unstrengthened opening and $\left(f_{\mathrm{cu}}=450\right)$ was shown in Fig (12), the first crack was initiated at the opening corner nearest to the support at a load of $1.5 \mathrm{t}$, and first crack at the mid span of beam was initiated at 2.10t. As the load increased, other cracks were observed at the top and bottom chord of opening, the beam failed at load of 4.2t. A horizontal crack was formed in the bottom and top chord of the opening. The mode of failure, as indicated by photo (11) was a typical shear failure.

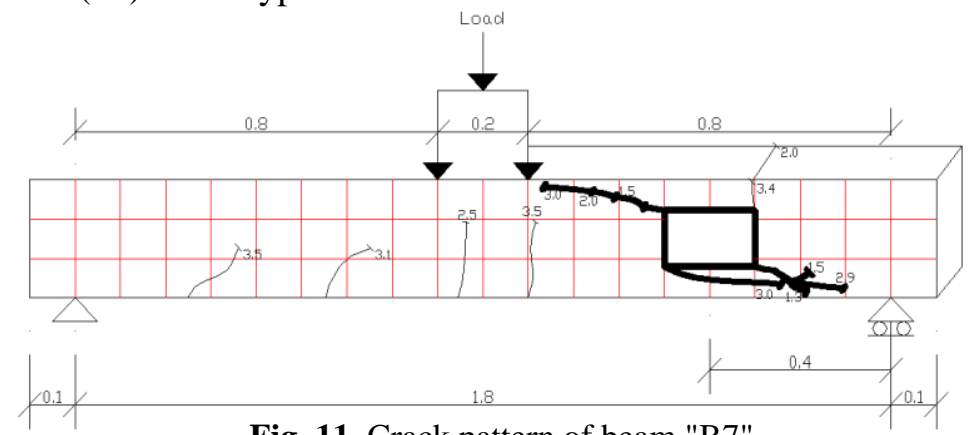

Fig. 11. Crack pattern of beam "B7". 

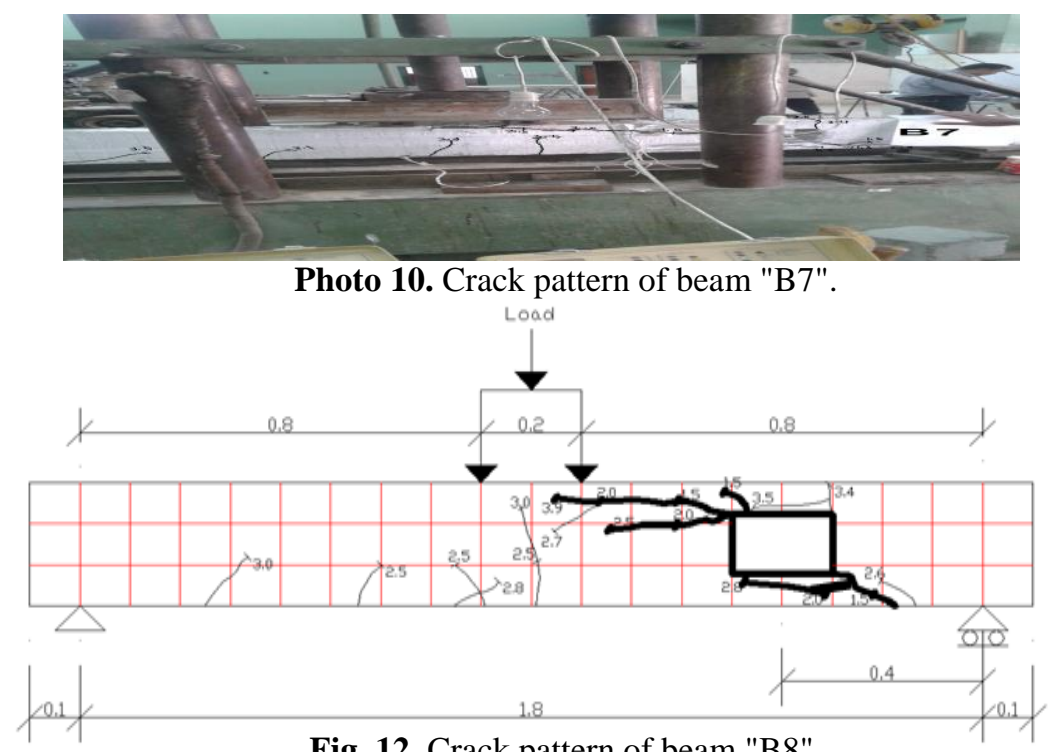

Fig. 12. Crack pattern of beam "B8".

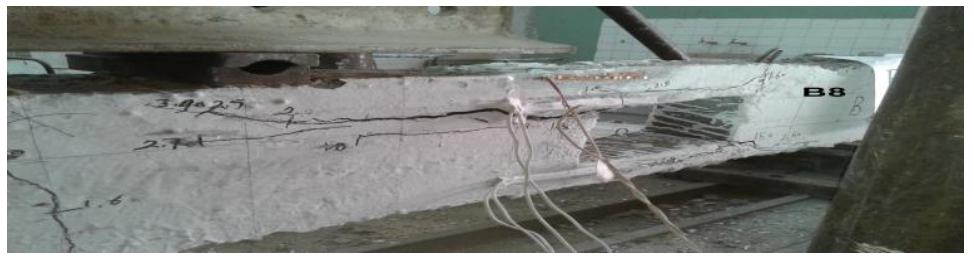

Photo 11. Crack pattern of beam "B8".

\subsubsection{Tested beams with different strengthening scheme, group $(D)$}

All the beams of this group "B9", "B10" and "B11" have a created opening which cut two vertical stirrups.

The crack pattern for beam "B9" with created unstrengthened opening, is shown in Fig (13). The first crack was initiated vertically at the mid span of beam at 1.5t, while first crack at the opening corner nearest to the support was initiated at a load of 2.0t. As the load increased, new cracks were observed in the top and bottom chord of opening, the beam failed by shear at load of 2.4t. A horizontal crack was formed prior to failure. The mode of failure, as indicated by photo (12) was shear failure.

Concerning the crack pattern for beam "B10" with opening strengthened by one layer CFRP. The first crack was initiated at the mid span of beam at, 2.5t. Fig (14). As the load increased, further flexural cracks were formed. Horizontal cracks were observed in the top and bottom chord of opening at a load of $4.5 \mathrm{t}$, the beam failed at load of 5.5t. The major crack was vertical at mid span, accompanied by tearing of the CFRP layer in the top and bottom chord. The mode of failure is a typical shear-flexural failure. A sound like CFRP rupture it was heard prior to failure. See photo (13).

The crack pattern for beam "B11" having a strengthened opening with two CFRP layers. No cracks were observed at the opening zone, and first crack was initiated at the mid span of beam at $2.5 \mathrm{t}$.

As the load increased, other vertical cracks initiated and extended towards the points of load 
Mostafa Ahmed Mohamed and M. M. Ahmed, Strengthening of R.C beams with openings .......

application. The mode of failure, as indicated by photo (14) was a typical flexural one; the beam failed at load of $6.56 \mathrm{t}$.

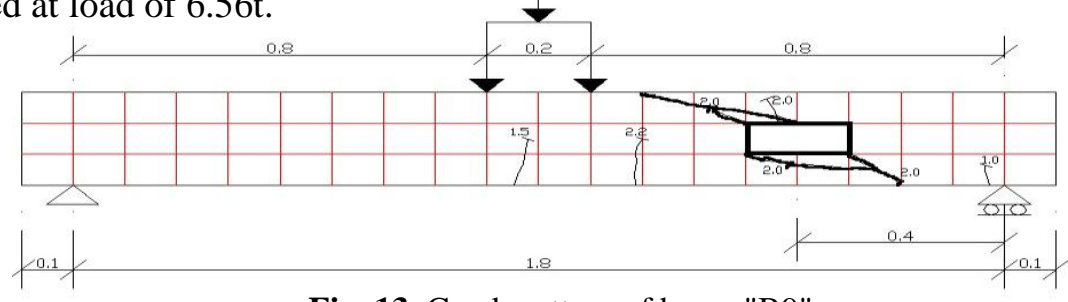

Fig. 13. Crack pattern of beam "B9".

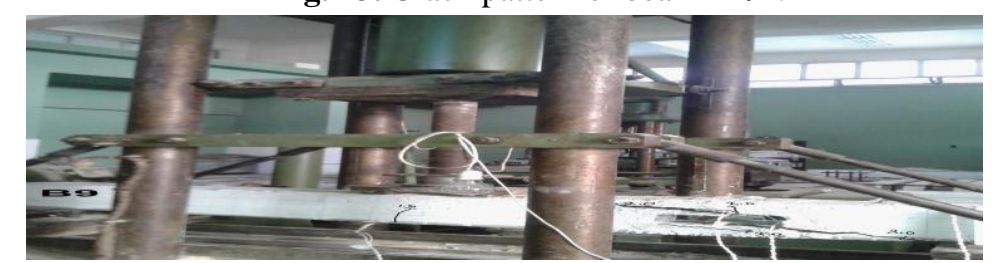

Photo 12. Crack pattern of beam "B9".

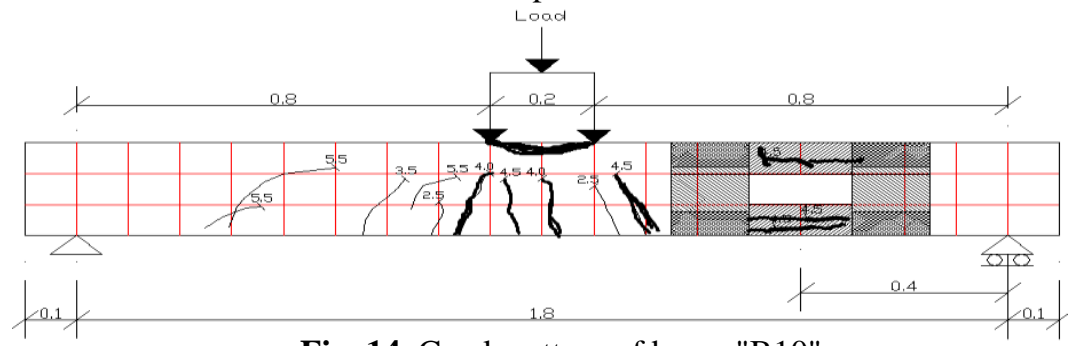

Fig. 14. Crack pattern of beam "B10".

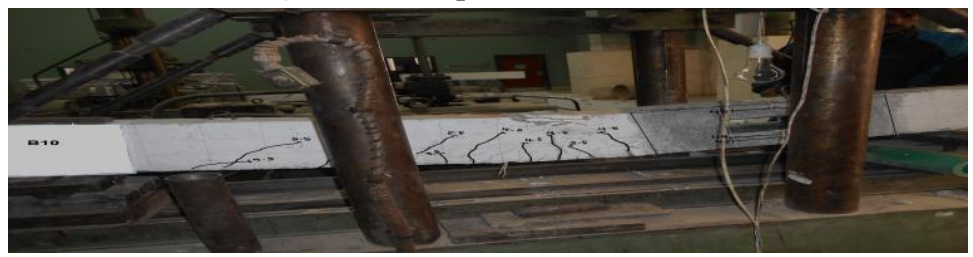

Photo 13. Crack pattern of beam "B10".

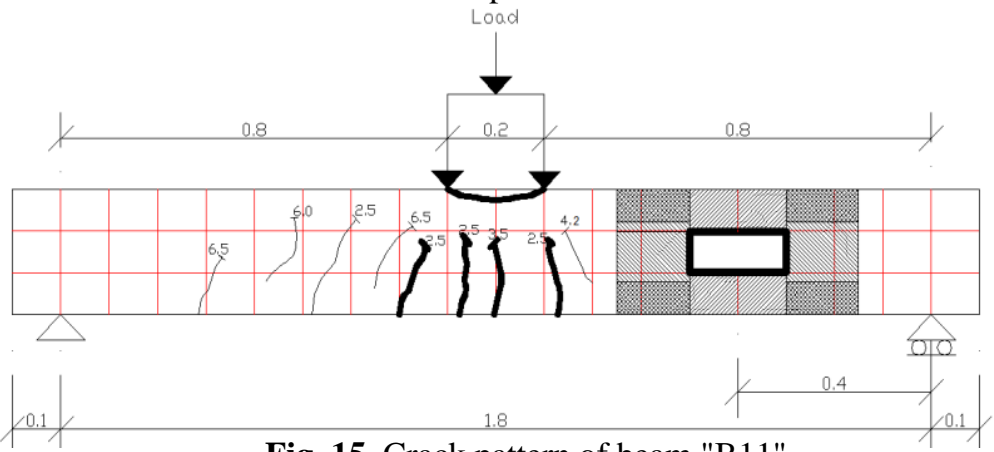

Fig. 15. Crack pattern of beam "B11".

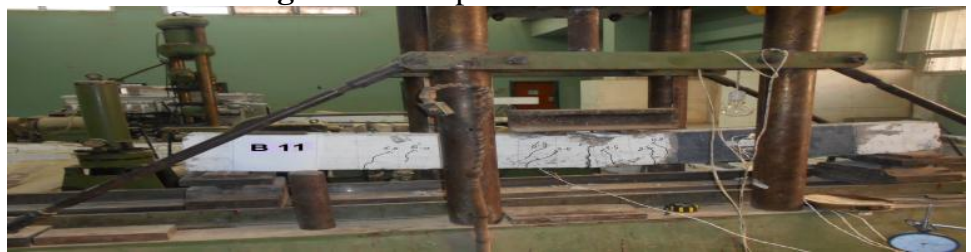

Photo 14. Crack pattern of beam "B11". 
2.1.5 Tested beams with different cut stirrups reinforcement ratio $\left(\rho_{s}\right)$, group $(E)$

The beams of this group were provided with an opening which cut variable number of stirrups and have variable distance between unaffected ( $\left.S^{\prime}\right)$ stirrups in the opening zone.

The pattern of cracks for beam "B11" with $\left(\mathrm{S}=42 \mathrm{~cm}, \rho_{s}=5.13 \times 10^{-5}\right)$ is mentioned before in item (2.1.4).

In the beam "B12" having an opening with one cut stirrups and ( $\mathrm{S}=28 \mathrm{~cm}, \rho_{s}=7.69 \times 10^{-}$ ${ }^{5}$ ), strengthened with two layers from CFRP, is shown in Fig (16), the first crack was initiated at the mid span of beam at 2.6t. As the load increased, other flexural cracks initiated and extended towards the points of load application. Diagonal cracks were observed in the solid shear zones without opening at 4.5t. The mode of failure, as indicated by photo (15) was a typical flexural failure accompanied by crushing of concrete in the compression zone at load of $6.90 \mathrm{t}$.

For beam "B13" having an opening with two cut stirrups and $\left(\rho_{\mathrm{s}}=4.49 \times 10^{-5}\right)$, strengthened with two layers CFRP is shown Fig (17), the distance between unaffected stirrup in the opening zone $=48 \mathrm{~cm}$. No cracks was initiated at opening zone, and first crack was initiated at the mid of beam at 2.0t. As the load increased, other cracks initiated and extended towards the points of load application. Diagonal cracks were observed in the solid shear zones at 3.0t. Extended from a vertical crack, the mode of failure, as indicated by photo (16) was a typical flexural one. The beam failed at load of 6.0t.
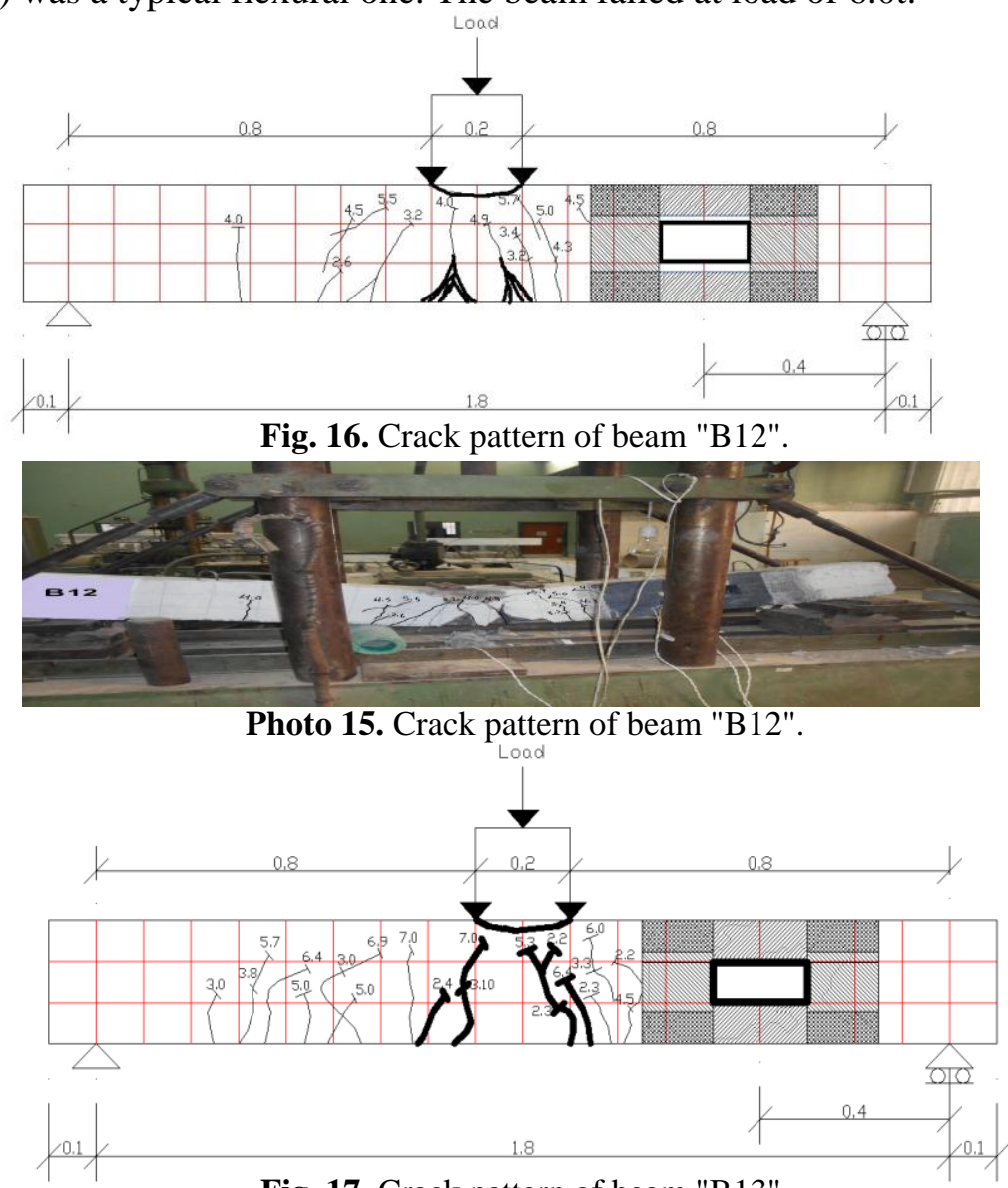

Fig. 17. Crack pattern of beam "B13". 


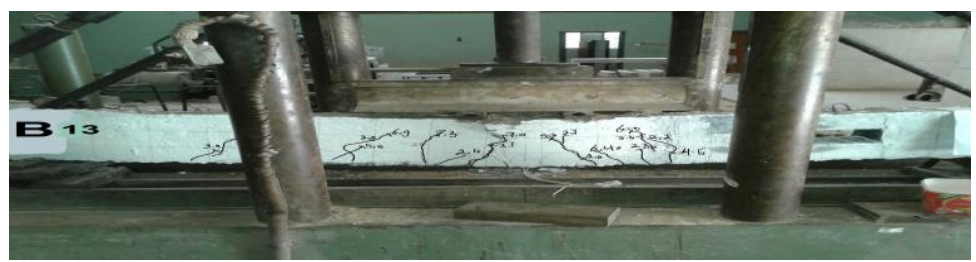

|Photo 16. Crack pattern of beam "B13".

\subsubsection{Tested beams with strengthened opening and variable $F_{c u}$, group $(F)$}

The crack pattern for beam "B14" having a strengthened opening with two layers from CFRP and $\left(\mathrm{f}_{\mathrm{cu}}=250\right)$, is shown Fig (18), the first crack was initiated at the mid span of beam at $1.5 \mathrm{t}$.

As the load increased, other cracks initiated and extended towards the points of load application. The mode of failure, as indicated by photo (17), was a typical shear failure accompanied by sound like CFRP rupture. the strengthening layers were removed to see the cracks in the concrete beneath them. Diagonal and horizontal cracks were observed in the top and bottom chord of opening

However For beam "B15" having a strengthened the same strengthening scheme as in "B14" but with $\left(\mathrm{f}_{\mathrm{cu}}=325 \mathrm{~kg} / \mathrm{cm}^{2}\right)$, the first crack was initiated at the mid span of beam at load level of about 2.0t. As the load increased, other cracks were initiated and extended towards the beam failed at load of 7.3t. The mode of failure, as indicated by photo (18) was a typical shear and flexural failure accompanied by sound like CFRP rupture. Horizontal cracks were observed after the removal of the strengthening layer in the top and bottom chord of the opening.

The crack pattern for beam "B16" $\left(\mathrm{Fcu}=450 \mathrm{~kg} / \mathrm{cm}^{2}\right)$ is shown in Fig (20). The first crack at the mid span of beam was initiated at 2.50t. As the load increased, other cracks were observed at the top and bottom chord of opening, the beam failed at load of 7.90t. Prior to failure horizontal cracks were formed in the strengthening at top and bottom chord of opening. The mode of failure, as indicated by photo (19) was a typical shear and flexural failure accompanied by sound like CFRP rupture.

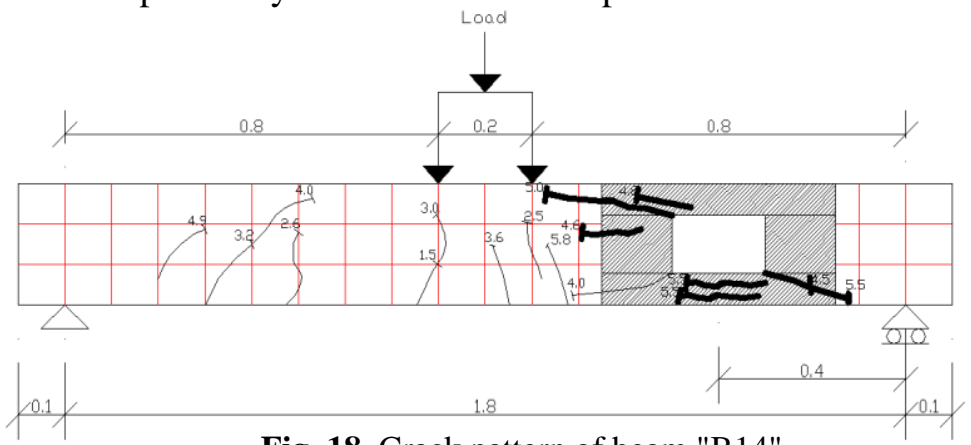

Fig. 18. Crack pattern of beam "B14".

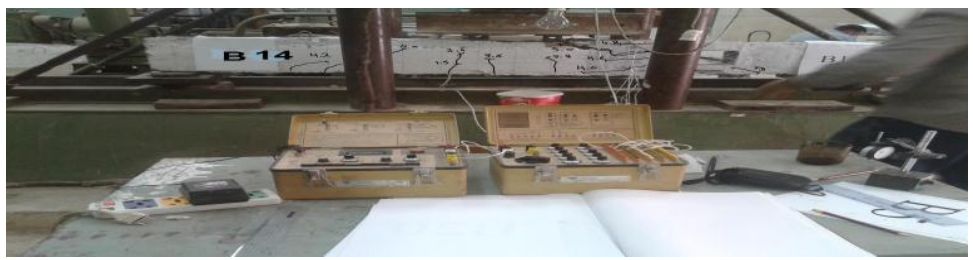

Photo 17. Crack pattern of beam "B14". 


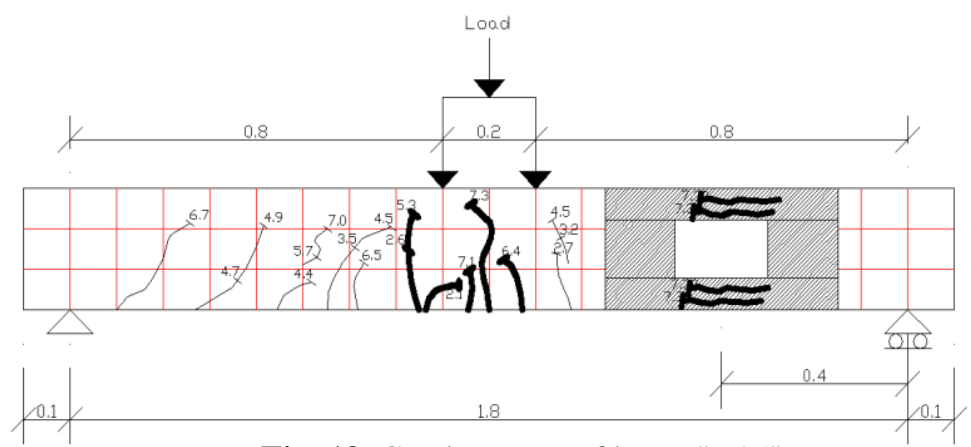

Fig. 19. Crack pattern of beam "B15".

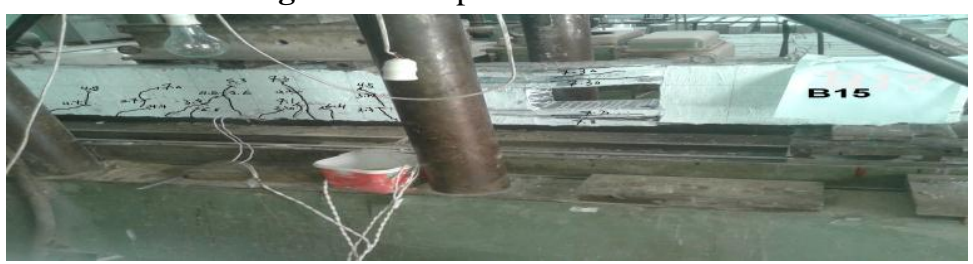

Photo 18. Crack pattern of beam "B15".

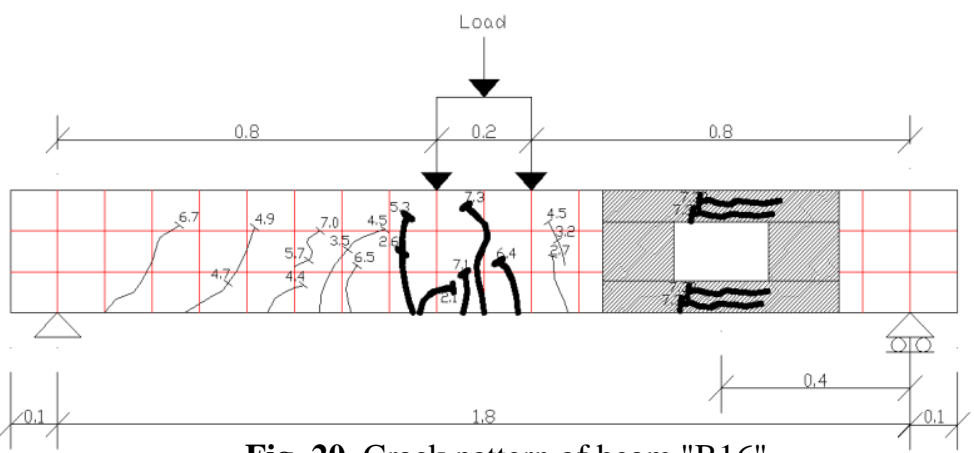

Fig. 20. Crack pattern of beam "B16".

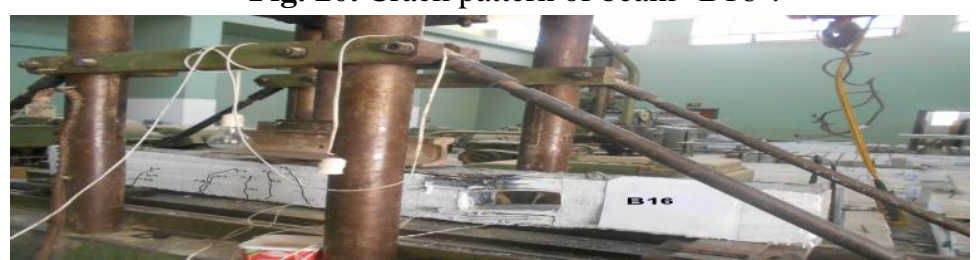

Photo 19. Crack pattern of beam "B16".

\subsection{Effect of opening on crack and ultimate load}

For beams "B2", "B3" and "B4" with variable unstrengthened opening height the first shear cracks was initiated in the opening zone at a load $2 \mathrm{t}, 1.5 \mathrm{t}$ and $1 \mathrm{t}$ respectively. As the opening height increased the cracking and ultimate load decreased. In beam "B2" having an opening height of $8 \mathrm{~cm}$, the ultimate load was $4 \mathrm{t}$, while for beam "B3" which has an opening height of $10 \mathrm{~cm}$, the ultimate load was $3.7 \mathrm{t}$. Finally for beam "B4" with opening height of $12 \mathrm{~cm}$, the ultimate load was $3.5 \mathrm{t}$. The value of ultimate loads of beams "B2", "B3" and "B4" compared with those of the solid reference beam "B01" were 54.79\%, $50.68 \%$ and $47.95 \%$ respectively, see Fig (21) and Fig (22). 


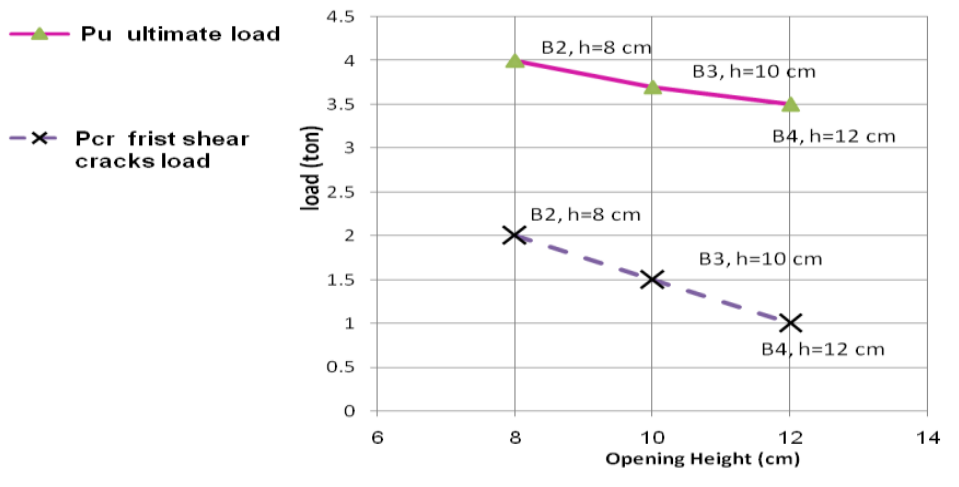

Fig. 21. Effect the opening height on the ultimate load and first shear cracks load.

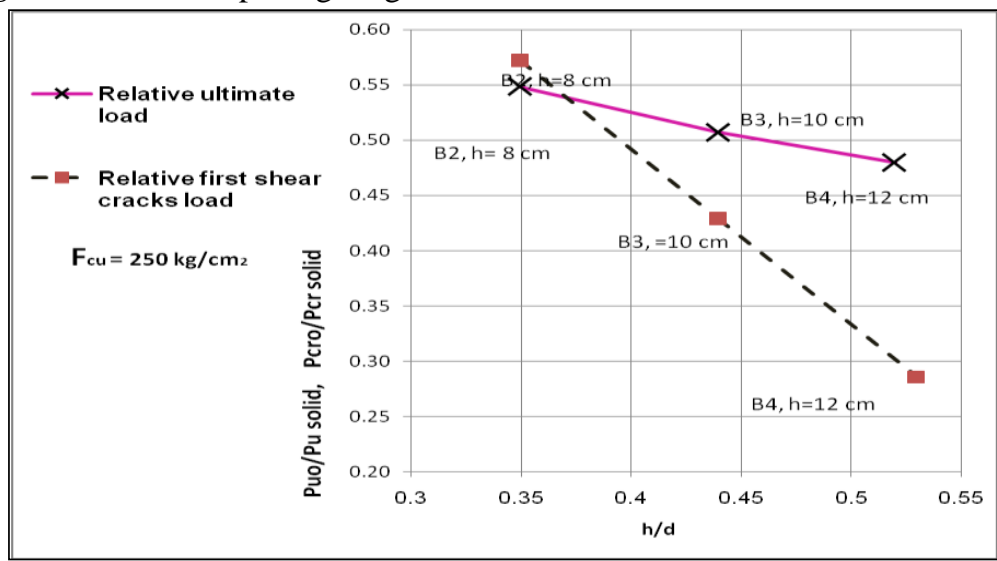

Fig. 22. Ultimate and first shear crack load relative to those of "B01" versus opening height ratio h/d

Also, strengthening the interior faces of the openings and around the openings on both sides of the beams by using one or two layers vertical and horizontal CFRP laminates increased the ultimate load; first shear cracks load and relative ultimate load as shown in Fig (23) and Fig (24).

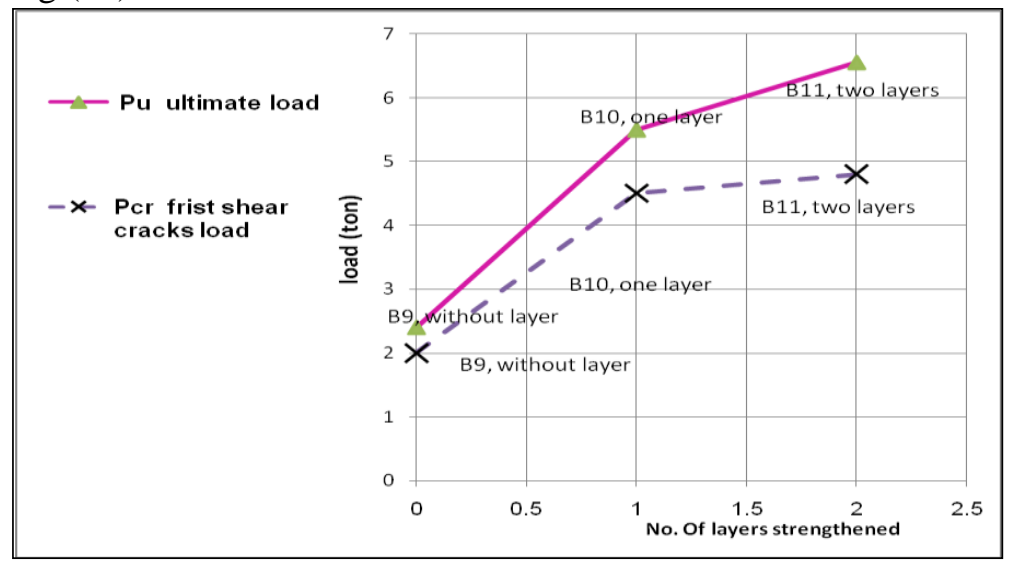

Fig. 23. Effect of Number of Layers CFRP Strengthening on the ultimate load and first shear cracks load. 


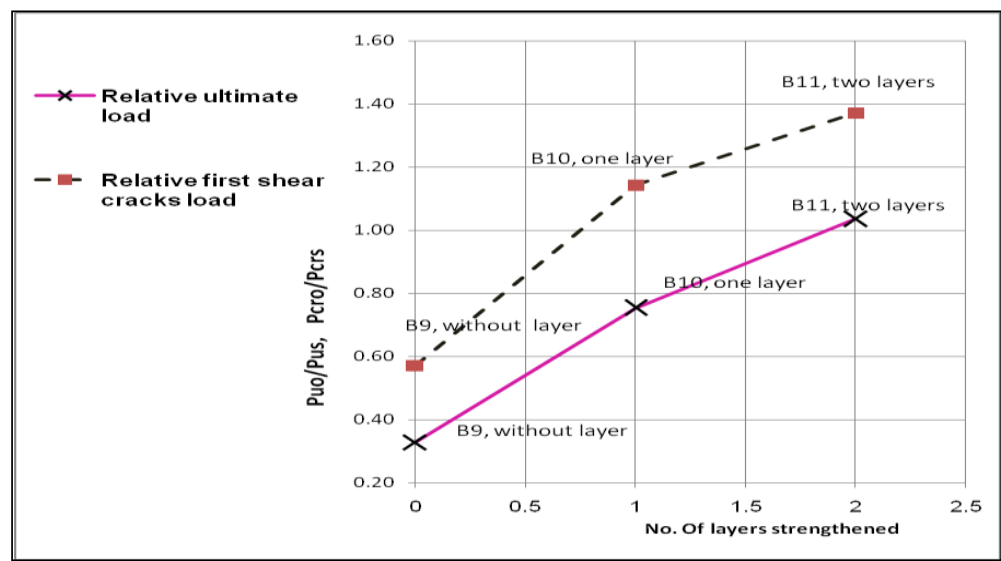

Fig. 24. Effect of Number of Layers CFRP Strengthening on the relative ultimate load and relative first shear cracks load

For beams "B14", "B15"and "B16", the concrete compressive strength was 250, 325, and 450 and the first shear cracks was at loads of 3.5, 7.0t and 7.50t, respectively. As the concrete compressive strength $\left(\mathrm{f}_{\mathrm{cu}}\right)$ increased the first shear cracks appeared later and ultimate load increased. The ultimate loads for the mentioned tested beams were 5.5t, 7.30t and 7.90t respectively.

\subsection{Deflection}

The measured values of mid span deflection at the bottom surface of the tested beams were plotted versus the corresponding applied load from zero loading up to failure, and are given in Fig (25) and Fig (26). As it was indicated in curves, the relation between the applied load and the corresponding deflection is approximately linear up to the cracking load. After cracking, deflection tends to deviate from linearity as the load increased, prior to failure, deflection increased rapidly and the curve became more flat.

The creation of openings had a noticeable effect on the mid span deflection. Deflection of the tested beams at any load level increased when providing an opening in their web compared with the solid beam Fig (25). In the same time as the opening height increased, the mid span deflection increased, the mid span deflection for beams B2, B3, B4 at about $50 \%$ of the failure load was $1.25,2.20$ and $3.31 \mathrm{~mm}$ respectively. See Fig (26).

Ductility factor is measured using various methods. it can be defined as the ratio of the ultimate deformation (curvature or deflection) to the deformation at first yield (or at the working stage). An accurate value of the ultimate deflection can be considered to that at $90 \%$ of failure load. The deflection at working load may be assumed to be that corresponding to about $50 \%$ of failure load. The ductility factor here was measured using the ratio of the deflection at load corresponding to about $90 \%$ of the failure load to that corresponding to about $50 \%$ of failure load. The ductility factor decreased as the opening height increased. Fig (27).

Strengthening of the opening zone noticeably reduced the mid span deflection, Fig (28). Mid span deflection for beam B12 strengthened with two layers at the opening zone was slightly smaller than that of the solid reference beam B01. This may attributed to the following reasons: 
- CFRP sheets around openings help in resisting stress concentration at opening corners and compensate the cut web reinforcement thus delaying cracking and controlling cracks propagation, which as a result increase the stiffness of the beam. - The virtual area of CFRP sheets, which confining concrete section above and below opening helps to strengthen those sections to act as one which improves stiffness of beam.
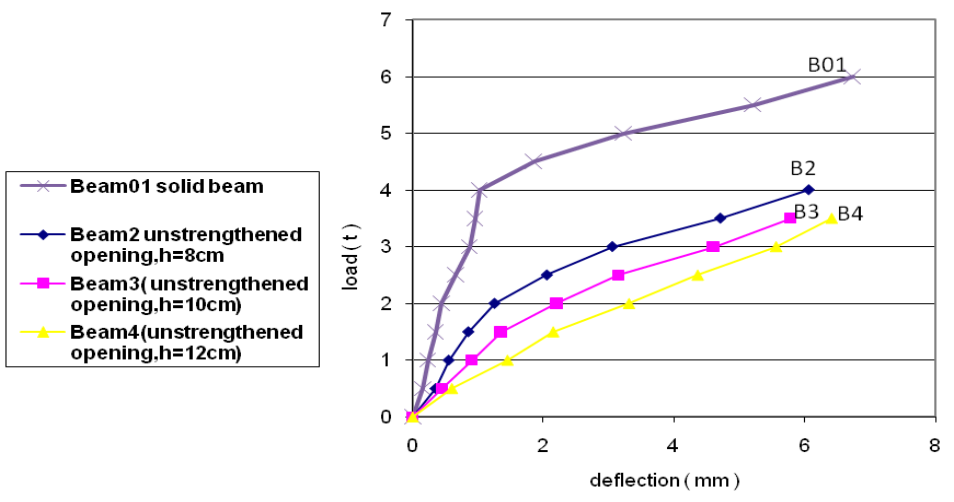

Fig. 25. Load-Deflection curves for beams"B2", "B3"and "B4" and "B01"

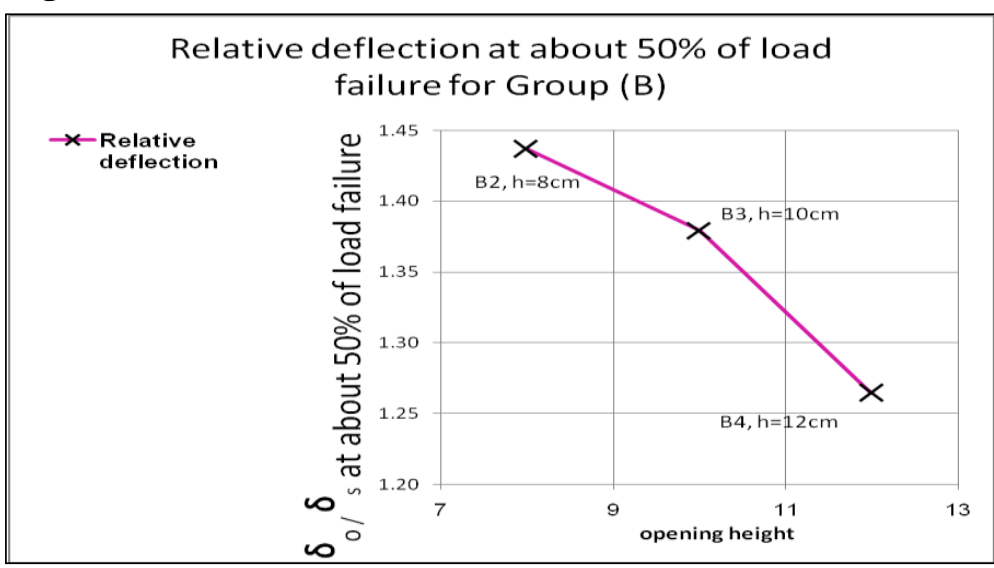

Fig. 26. Relative deflection for beams"B2", "B3"and "B4"

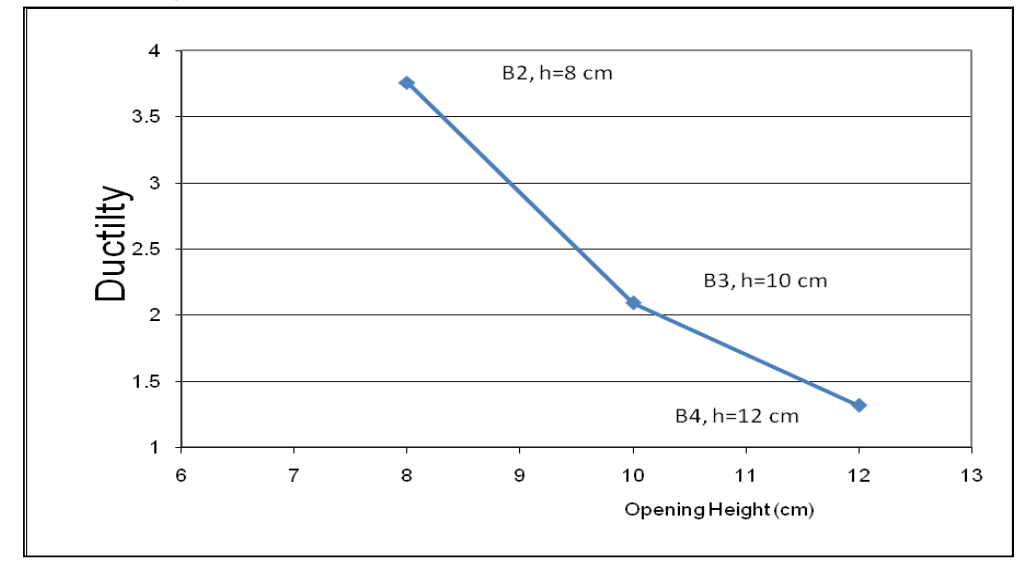

Fig. 27. Effect the opening height on Ductility 


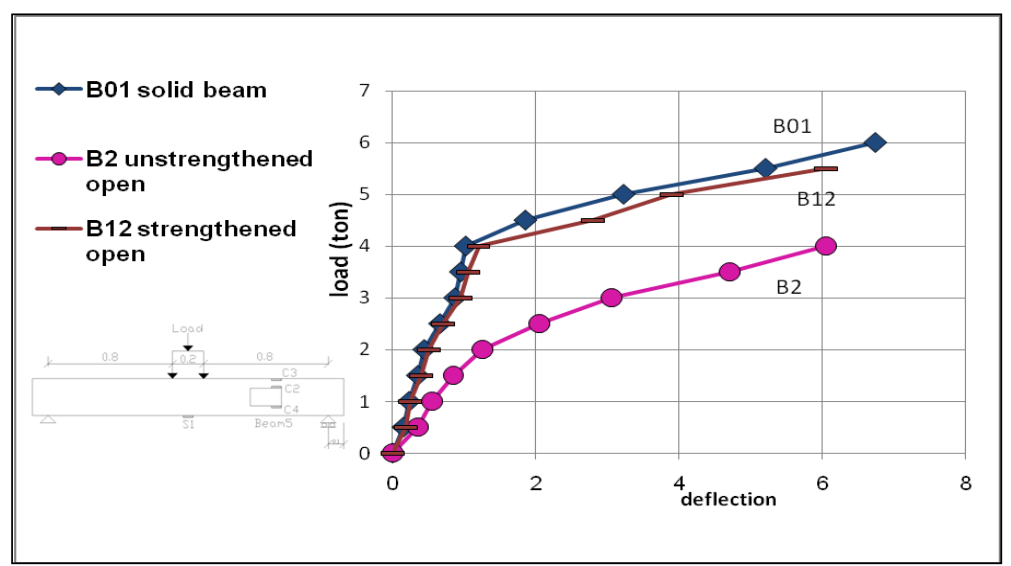

Fig. 28. Load-Deflection curves for "B01", "B2" and "B12"

\section{Conclusions}

From the tests carried out herein on reinforced concrete beams having opening created after casting, the following conclusions can be drawn:

1- Creating web opening in an existing R.C. beam largely increased mid span deflection, and decreased both the cracking and ultimate load. This effect increased as the opening height increased or as the number of cut stirrup increased.

2- Creating web opening in R.C. beams changed the pattern of cracks and the mode of failure from flexural to shear failure.

3- Strengthening openings with CFRP sheets contribute in reducing deflection, number of cracks; crack widths and can change the mode failure.

4- Strengthening the opening zone with CFRP sheets, improved the structural behavior of the perforated beams and can restore the original level of safety and serviceability of the beam within the range of variables considered in this work.

5- Improving the structural behavior of the perforated R.C. beam increasing as the number of strengthening layers increased.

\begin{tabular}{|c|c|}
\hline \multicolumn{2}{|c|}{ NOMERCLUTURE } \\
\hline $\mathrm{a} / \mathrm{d}$ : Shear span to depth ratio. & $a_{0}:$ Opening length the beam \\
\hline $\mathrm{h}_{\mathrm{fe}}$ : Effective height of FRP on the sides of the beam. & h: opening height. \\
\hline$\delta_{\mathrm{cr}}:$ Maximum deflection at first cracking load & $\delta:$ Deflection \\
\hline $\begin{array}{l}\delta_{\mathrm{ul}} \text { : Maximum mid span deflection stirrups at } \\
\text { ultimate load }\end{array}$ & a: distance between the force and support of beam \\
\hline d: depth of beam & $\begin{array}{l}S^{\prime}: \text { distance between unaffected on the } \\
\text { two sides of the opening }\end{array}$ \\
\hline$\rho_{\mathrm{s}}:$ Stirrups reinforcement ratio $\left(\mathrm{A}_{\mathrm{st}} / \mathrm{b} . \mathrm{s}^{\prime}\right)$ & b: width of beams cross sections \\
\hline
\end{tabular}




\section{REFERENCES}

[1] N. F. Grace, G. A. Sayed, A. K. Soliman and K. R. Salah"Strengthening Reinforced Concrete Beams Using Fiber Reinforced Polymer (FRP) Laminates" ACI Structure journal, V.96, 5, September- October 1999.

[2] O. Ahmed and D. Van Gemert "Effect of Longitudinal Caron Fiber Reinforced Plastic Laminates on Shear Capacity of Reinforced Concrete Beams", Fourth International Symposium on FRP for R.C Structures, SP-188, American Concrete Institute (ACI), 1999.

[3] Mahmoud T. El - Minhilmy and Joseph W. Tedesco "Deflection of Reinforced Concrete Beam Strengthened with Fiber-Reinforced Polymer (FRP) Plates", ACI Structural Journal, V.97, No. 5, September-october 2000.

[4] Alex Li, Jules Assih, and Yves Delmas "Shear Strengthening of RC Beams with Externally Bonded CFRP Sheets", Journal of Structural Engineering, Vol. 127, No. 4, April, 2001.

[5] Xinbao Yang and Antonio Nanni "Concrete Beams Strengthened with Misalingned CFRP Laminates", Accepted for Publication in Proceedings of FRPRCS5, Non-Metallic Reinforcement for Concrete Structures, Cambridge, UK, July 2001.

[6] Y. H. Hammad, G. T. Abdel-Rahman, S. Abdel-Gawad Aly, and M. said "Shear Behavior of RC T-Beams Strengthened with Wraps", Structural Composites for Infrastructure Applications, Aswan, Egypt, December, 2002.

[7] Sergio F. Brena, Regan M. Bramblett, Sharon L. Wood, and Michael E. Kreger "Increasing Flexural Capacity of Reinforced Concrete Beams Using Carbon Fiber-Reinforced Polymer Composites", ACI Structural Journal, V.100, No. 1, January-february 2000.

[8] J. Barros and S. Dais "shear Strengthening of Reinforced Concrete Beams with Laminate Strips of CFRP" Proceeding of The International Conference Composites in Constructions-CCC2003, Cosenza, Italy, September2003.

[9] Francesco Bencardino, Vincenzo Colotti, Giuseppe Spadea, and Ramnath N. Swamy "Are RC Beams Strengthened For Flexure Safe in shear?", Structural Composites for Infrastructure Applications, Alexandria, Egypt, 2005.

[10] Venees Faied Ibrahem Gerges, "Strengthening of R.C Beames With Openings Created After Casting Using F.R.P" M. Sc.Thesis, Helwan University, Mataria, Cairo, Egypt 2007.

[11] Mahmoud Abdou Mahmoud Hassanean(2014) Behavior of High Performance R.C. Continuous Deep Beams with Openings and Its Strengthening. M. Sc.Thesis, Assiut University Assiut, Egypt 2014. 


\section{تقوية الكمر ات الخرسانية سابقة الصب بعد عمل فتحات بها}

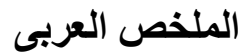

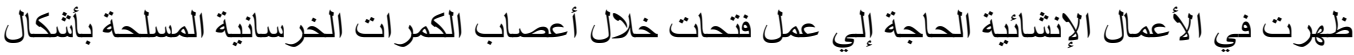

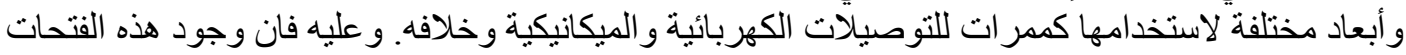

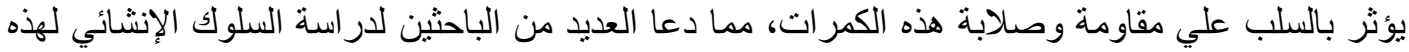

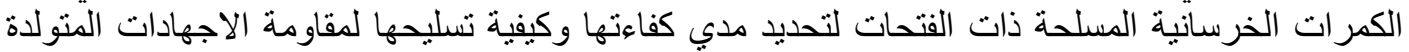
فيها نتيجة للأحمال الو اقعة عليها.

وقد توصل الباحثون في هذا المجال لنتائج طيبة من حيث قدرتهم علي تحديد الثكل و المقاس للفتحة

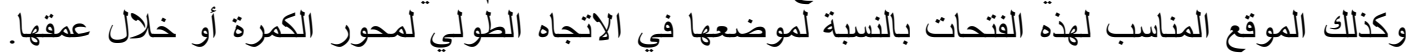

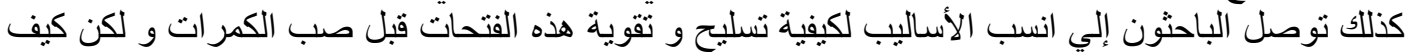

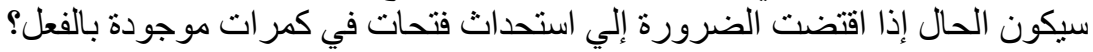
البحث القائم يحاول الإسهام في الإجابة عن السؤ ال حيث تم استخدام ألياف الكربون لتدعيم وتحسين سلوك الفتحات في الكمر ات.

ولذلك تم صب ثمانبة عشر كمرة ذات قطاع مستطيل و تم اختبار هم تحت حملين مركزين. و تم اخذ ثلاث

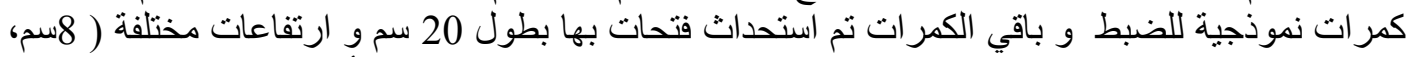
10 سم، 12 سم ) و قسمت إلي ستة مجموعات وتم التم اختبار جميع الكمرات ومن أهم النتائج التي تم التوصل

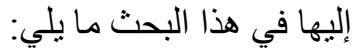

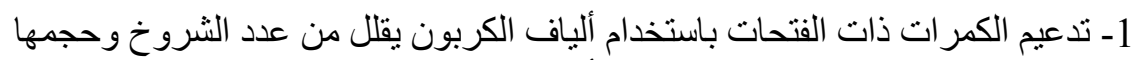

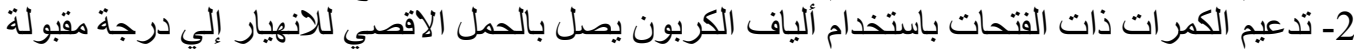

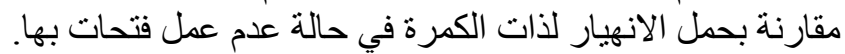

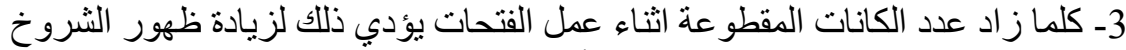

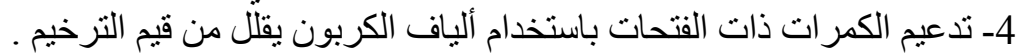

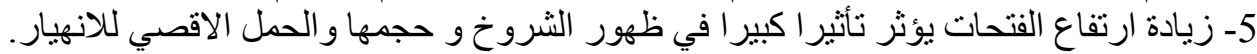

